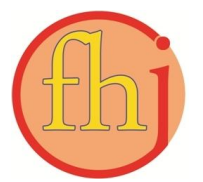

Faletehan Health Journal, 5 (3) (2018) 129-134

www. journal.Ippm-stikesfa.ac.id/ojs/index.php/FHJ

ISSN 2088-673X | e-ISSN 2597-8667

\title{
Hubungan Supervisi Keperawatan dengan Perilaku Caring Perawat dalam Merawat Pasien Kritis
}

\author{
Rohmatulloh ${ }^{1 *}$, Ani Haryani ${ }^{1}$ \\ ${ }^{1}$ Sekolah Tinggi IImu Kesehatan Faletehan Serang, Indonesia \\ *Corresponding Author: matz.omat14@gmail.com
}

\begin{abstract}
Abstrak
Perilaku Caring merupakan kunci dalam meningkatkan kualitas pelayanan keperawatan. Caring merefleksikan sebuah kebaikan danrasa kepedulian.Perilaku Caring perawat dalam merawat pasien kritis menjadi kunci keberhasilan perawatan mengingat kondisi pasien kritis dengan tingkat ketergantungan penuh. Supervisi keperawatan telah diidentifikasi menjadi salah satu faktor eksternal yang mempengaruhi perilaku caring. Penelitian ini bertujuan untuk mengetahui Hubungan antara supervisi keperawatan dengan perilaku caring perawat dalam merawat pasien kritis. Penelitian menggunakan desain analitik korelasi dengan pendekatan cross sectional. Teknik sampling menggunakan total sampling dengan jumlah 60 orang yang merupakan perawat pelaksana yang ada diruang IGD, ICU, dan HCU. Hasil penelitian menunjukkan rerata Perilaku Caring perawat adalah 87 (SD 10), rerata Supervisi keperawatan adalah 45 (SD 7). Hasil uji korelasi dan regresi linear sederhanamenunjukan adanya hubungan antara supervisi keperawatan dengan perilaku caring perawat ( $p$ value $=0.000$ ), dengan kekuatan hubungan sedang dan berpola positif $(r=0,502)$, dan nilai koefisien dengan determinasi sebesar 0,252. Supervisi yang dilakukan dengan baik dapat meningkatkan perilaku caring perawat dalam merawat pasien kritis.
\end{abstract}

Kata Kunci: Perawatan Kritis, Perilaku caring,Supervisi Keperawatan

\begin{abstract}
Caring behavior is a key for developing nursing care quality. Caring reflects kindness, and sense of care. Nurses caring behavior become a key for nursing care success in caring of critical patients according to full dependence level of patients.Nursing Supervision has been identified as one of the eksternal factors that influence caring behavior. The purpose of this study was to determine the relationship between nursing supervision and nurse caring behavior in caring for critical patients. This study used correlation analytic design with cross sectional approach. The sampling technique uses total sampling with a total of 60 people sampling by total sampling technique with 60 nurses in the Emergency room, ICU, and HCU.The results of the study showed that the average Caring Behavior of nurses was 87 (SD 10), mean nursing supervision was 45 (SD 7). Correlation and simple linear regression results showed a relationship between nursing supervision and nurse caring behavior ( $p$ value $=0.000$ ), with the strength of the relationship being positive and patterned $(r=0.502)$, and the coefficient with determination of 0.252 . W ell-done supervision can improve nurses' caring behavior in caring for critical patients.
\end{abstract}

Keywords: Caring Behavior, Critical Care, Nursing Supervision 
Faletehan Health Journal, 5 (3) (2018) 129-134

www. journal.Ippm-stikesfa.ac.id/ojs/index.php/FHJ

ISSN 2088-673X| 2597-8667

\section{Pendahuluan}

Pemerintah Republik Indonesia manyatakan bahwa mutu pelayanan keperawatan perlu ditingkatkan demi kesejajaran keperawatan di Indonesia dengan Negara-negara di ASEAN dalam mewujudkan pelayanan keperawatan yang prima. Perilaku caring merupakan salah satu bagian terpenting yang dapat menunjang untuk mewujudkan hal tersebut. Pernyataan tersebut sesuai dengandeklarasi perawat Indonesia yang menyatakan bahwa perilaku caring sebagai kunci dalam meningkatkan mutu dan kualitas pelayanan keperawatan yang prima (Kementrian Kesehatan Republik Indonesia, 2012).

Sampai saat ini, pada realitas pelayanan keperawatan, belum semua perawat menunjukkan perilaku caring yang baik. Hal ini dapat diidentifikasi pada beberapa penelitian tentang perilaku caring perawat. Penelitian Tiara (2013) yang meneliti perilaku caring96 perawat menunjukkan sebagian besar $(56,3 \%)$ perawat menunjukkan perilaku caring dalam kategori kurang. Penelitian lain yang dilakukan oleh Desima (2013) pada 42 orang perawat juga menunjukkan sebagian besar $(71,43 \%)$ perawat berperilaku caring yang kurang. Kedua penelitian tersebut memberikan gambaran bahwa perilaku caring perawat kurang baik. Hal ini tentunya sangat disayangkan, mengingat perilaku caring merupakan inti dari pelayanan keperawatan. Demikian halnya Kozier, Erb, Berman, dan Snyder (2010) menyatakan bahwa "Caring merupakan intisari keperawatan dan karakteristik yang dominan, khusus, serta tidak terpisahkan dalam keperawatan". Sehingga penting bagi seorang perawat dalam meningkatkan perilaku caring nya.

Sebagai upaya untuk meningkatkan perilaku caring perawat, dalam beberapa penelitian telah diidentifikasi bahwa menerapkan metode supervise keperawatan dapat menjadi salah satu soluasi. Penelitian Muttaqin (2008) menunjukkan bahwa supervisi keperawatan yang dilakukan oleh kepala ruangan memiliki hubungan yang berarti dengan perilaku caring perawat.Penelitian lain yang dilakukan oleh Lazzerini, dkk (2017) terkait dengan supervisi untuk meningkatkan kualitas pelayanan perawatan juga menunjukkan bahwa kelompok yang dilakukan intervensi supervisi memiliki peningkatan kualitas pelayanan yang dirasakan oleh pasiennya.
Berdasarkan beberapa penelitian sebelumnya dapat dikatakan jika supervisi mempunyai pengaruh terhadap perilaku caring perawat. Namun demikian penelitian terkait dengan supervisi terhadap perilaku caring perawat di Indonesia masih sangat sedikit. Baik penelitian Muttaqin (2009) maupun Lazzerini, dkk (2017) keduanya dilakukan di ruang rawat inap biasa dan belum ditemukan penelitian sejenis yang dilakukan di ruang perwatan pasien kritis. Sesuai dengan kondisinya, pasien kritis merupakan pasien yang memiliki kebutuhan yang berbeda dengan pasien di ruang rawat inap biasa, karena kondisi pasien kritis yang tidak stabil dan terpasang alat-alat yang dapat menimbulkan distress tersendiri sehingga membutuhkan perawatan yang ekstra dari seorang perawat (Jakimowich dan Perry, 2015).

Perilaku caring perawat dalam merawat pasien kritis merupakan hal yang menarik untuk diteliti, dan apakah supervisi klinis juga mempunyai pengaruh terhadap perilaku caring perawat dalam merawat pasien kritis mengingat tingkat kebutuhan dari pasien kritis yang semuanya sangat bergantung pada perawat. Sebuah penelitian di London yang meneliti pengaruh supervisi diruang perawatan kritisyang dilakukan oleh oleh Elzenny, Saeda, dan Ettewy (2017) menunjukkan bahwa supervisi dalam hal ini supervise klilnis memberikan korelasi yang positif terhadap peningkatan kualitas pelayanan keperawatan. Namun demikian penelitian ini juga belum menunjukkan secara langsung keterkaitan antara supervisi dengan perilaku caring yang menjadi bagian penting pelayanan keperawatan.

Berdasarkan hasil penelusuran literature tersebut maka peneliti tertarik untuk melakukan penelitian yang menghubungkan antara supervisi keperawatan dengan perilaku caring perawat dalam merawat pasien kritis. Tujuan penelitian ini untuk mengetahui hubungan antara supervisi keperawatan dengan perilaku caring perawat dalam merawat pasien kritis.

\section{Metode Penelitian}

Desain penelitian yang digunakan adalah analitik korelasi dengan menggunakan pendekatan cross sectional. Penelitian dilakukan di Rumah Sakit dr. Dradjat Prawiranegara (RSDP) Serang pada bulan Mei-Juli 2018. Populasi pada penelitian ini adalah semua perawat yang ada diruang ICU, HCU dan ruang UGD. Perawat Ruang UGD 
Faletehan Health Journal, 5 (3) (2018) 129-134 www. journal.Ippm-stikesfa.ac.id/ojs/index.php/FHJ ISSN 2088-673X| 2597-8667

dilibatkan dalam penelitian dengan pertimbangan bahwa ruang UGD RSDP memiliki kapasitas tempat tidur yang cukup besar yaitu 9tempat tidur untuk pasien Prioritas 1 dan semua perawat secara bergiliran ditempatkan pada area tersebut. Pasien dengan prioritas 1 merupakan pasien dengan kategori merah dan memiliki karakteristik pasien kritis. Pengambilan sampel dalam penelitian ini menggunakan metode total sampling, yaitu dengan melibatkan seluruh perawat pelaksana yaitu sejumlah 60 orang.

Perilaku caring perawat diukur dengan menggunakan Kuesioner yang dikembangkan dari Caring Behavior Assessment (CBA) dari Cronin dan Harrison yang telah dimodifikasi dan di uji validitas dalam penelitian Mulyaningsih (2011), Nurmalasari dan Haryani (2017) dan kuesioner kemudian dimodifikasi kembali oleh peneliti serta disesuaikan dengan karakteristik aktivitas caring pada pasien kritis. Uji validitas dilakukan pada 22 orang responden dan didapatkan 13 item pernyataan yang dinyatakan valid dan reliable (Cronbacth alfa 0,893).Supervisi keperawatan diukur dengan menggunakan kuesioner yang telah digunakan oleh Muttaqin (2008) yang terdiri dari 17 pernyataan untuk mengetahui supervisi yang dilakukan oleh kepala ruangan pada perawat pelaksana. Hubungan kedua variable dianalisis dengan menggunakan Uji Korelasi regresi sederhana dari Pearson.

\section{Hasil dan Pembahasan \\ Gambaran Karakteristik Responden}

Berdasarkan Tabel 1 didapatkan bahwa sebagian besar perawat yang menjadi responden dalam penelitian ini berjenis kelamin laki-laki (65\%), berpendidikan DIII Keperawatan (68\%), rata rata usia perawat adalah 29,50 tahundan rata rata lama kerja adalah 7 tahun.

\section{Gambaran Perilaku Caring Perawat}

Tabel 2. menunjukan bahwa dari total 60 responden yang diteliti diketahui sebagian besar responden memiliki perilaku caring. Dengan hasil rata-rata skor perilaku caring perawat adalah 87, dengan standar deviasi 10.Perilaku caring pada hasil penelitian ini dimungkinkan dipengaruhi oleh karakteristik perawat salah satunya adalah lama kerja perawat. Hini sejalan dengan penelitian Prayitno, Saryono, dan Sarwono (2011) yang menunjukan bahwa ada hubungan yang bermakna antara lama kerja perawat dengan kepuasan pasien, dalam penelitian ini kepuasan pasien yang diukur salah satunya adalah perilaku caring dari perawat. Pada penelitian ini rata rata lama kerja perawat adalah 7 tahun dimana lama kerja tersebut menunjukkan waktu yang cukup untuk membentuk perilaku caring seorang perawat.

Hasil penelitian lain yang juga menunjukkan pengaruh lama kerja terhadap perilaku caring adalah hasil penelitian Angelina, Kumaat dan Mulyadi (2017) pada perawat UGD. Hasil penelitian menunjukkan sebagian besar perawat yang bekerja di IGD berperilaku caring yaitu $76,7 \%$ dimana rata rata lama kerja perawat adalah 7 tahun. Dalam kurun waktu tersebut perawat lebih sering dan lebih mengenal latar belakang pasien dan keluarga, sehingga perilaku caring perawat dapat menjadi lebih baik.

Namun demikian pada penelitian ini masih terdapat $45 \%$ responden yang perilaku caring nya masih dalam kategori kurang caring. Berdasarkan hasil isian dalam kuesioner, beberapa item pertanyaan yang memiliki nilai masih rendah adalah tentang komunikasi. Dalam arti lain belum semua perawat terbiasa melakukan komunikasi yang intensif dengan pasien terkait mengungkapkan perasaan dan memberikan pendidikan kesehatan.

\section{Tabel 1. Distribusi Frekuensi Jenis Kelamin, Pendidikan, Usia dan Lama Kerja Perawat $(n=60)$}

\begin{tabular}{lcc}
\hline \multicolumn{1}{c}{ Karakteristik } & F & \% \\
\hline Jenis kelamin balita & & \\
$\quad$ Perempuan & 39 & 65 \\
$\quad$ Laki-laki & 21 & 35 \\
\hline Pendidikan & & \\
$\quad$ DIII Keperawatan & 41 & 68 \\
$\quad$ S1 Keperawatan & 5 & 9 \\
$\quad$ Ners & 14 & 23 \\
\hline Usia & & \\
$\quad \leq 29$ tahun & 34 & 56.7 \\
$\quad>7$ tahun & 26 & 43.3 \\
Median: 7.0, SD: 5.5, CI(95\%): 7.7-10.5, Min:3, Max:28 \\
\hline
\end{tabular}

\section{Tabel 2.Distribusi Frekuensi Perilaku Caring Perawat Dalam Merawat Pasien Krits (n=60)}

\begin{tabular}{ccc}
\hline Perilaku Caring & F & \% \\
\hline Caring & 33 & 55 \\
Kurang Caring & 27 & 45 \\
Mean: 87, SD: 10, C.I (95\%) & $:$ 84-94, Min: 67, Max: 100 \\
\hline
\end{tabular}


Salah satu peran perawat dalam merawat pasien kritis adalah memberikan pelayanan keperawatan melalui pemeliharaan emosional juga berperan sebagai komunikator.

Tanpa adanya komunikasi antara perawat dengan keluarga ataupun pasien maka akan sulit untuk memberikan kenyamanan dan memelihara emosional. Penelitian Fajrillah dan Nurfitriani (2016) menunjukan bahwa komunikasi khususnya komunikasi terapeutik perawat berpengaruh terhadap kepuasan pasien. Dimana komunikasi terapeutik merupakan bagian dari perilaku caring yang di tunjukan oleh perawat.

Seorang perawat mempunyai tanggung jawab untuk menerapkan perilaku caring, karena dapat mempengaruhi pelayanan.Upaya peningkatan caring dapat dilakukan melalui pendekatan individu, psikologi dan organisasi. Pendekatan individu dapat dilakukan dengan cara meningkatkan pengetahuan dan keterampilan melalui pelatihan, mengikuti seminar ataupun meningkatkan pendidikan formal (Indrastuti 2010). Upaya lain untuk meningkatkan perilaku caring adalah melalui pelatihan peningkatan perilaku caring. Penelitian Susihar (2011) tentang pengaruh pelatihan perilaku caring terhadap motivasi perawat dan kepuasan pasien menunjukkan bahwa terdapat peningkatan yang signifikan antara penerapan perilaku caring perawat, motivasi perawat, serta kepuasan pasien setelah perawat mengikuti pelatihan tersebutPendekatan organisasi dapat dilakukan melalui perencanaan pengembangan imbalan atau yang terkait dengan kepuasan kerja perawat serta adanya kepemimpinan yang efektif dalam keperawatan (Putri, 2014).

\section{Gambaran Supervisi Keperawatan}

Berdasarkan Tabel 3 menunjukan bahwa dari total 60 responden yang diteliti mempersepsikan bahwa kegiatan supervise keperawatan oleh kepala ruangan adalah baik (48\%).

Hasil penelitian tentang supervisi klinis menunjukan sebagian responden (52\%) dalam kategori baik, ditinjau dari jawaban kuesioner didapatkan beberapa item pernyataan dalam kategori baik adalah membuat keputusan tentang perencanaan dan pengorganisasian, melakukan pemantauan kegiatan keperawatan dan nonkeperawatan, melakukan koreksi dan evaluasi. Namun demikian beberapa item pernyataan yang rata-rata nilai jawabannya masih rendah oleh responden yaitu memberikan arahan langsung dan tidak langsung, dan melakukan penilaian kinerja staff.

Masih rendahnya penilaian responden terhadap aktivitas kepala ruangan dalam memberikan arahan langsung dan tidak langsung dapat memberikan dampak tidak maksimalnya pencapaian tujuan supervise. Masna, Abdullah, dan Hasmin (2017) mengungkapkan bahwa seorang manager dalam memimpin bawahannya harus mampu memberikan dorongan, pengarahan, bimbingan, penyuluhan, pengendalian, keteladanan dan bersikap jujur serta tegas agar para bawahannya mau bekerja sama dan bekerja efektif untuk mewujudkan tujuan yang dinginkan. Memberikan arahan dalam supervisi merupakan peran dari seorang supervisor, jika peran tersebut tidak dijlankan atau terlaksana secara maksimal tentu tujuan dari supervisi tidak akan tercapai.

Upaya dalam mengatasi supervisi yang kurang dalam hasil penelitian ini dapat dilakukan dengan mempertahankan dan meningkatkan supervisi yang dilakukan oleh supervisor (kepala /wakil kepala ruangan) dengan mengutamakan tujuan yang ingin ditingkatkan melalui supervisi. Hal ini sejalan dengan hasil penelitian Masna, Abdullah, dan Hasmin (2017) mengatakan jika seorang kepala ruangan perlu mempertahankan dan meningkatkan supervisi yang telah ada dengan mengutamakan apa yang disupervisi, dimana dalam pelaksanaan supervisi yang menjadi target sasaran ketika melakukan supervisi yaitu kinerja perawat dan staf.

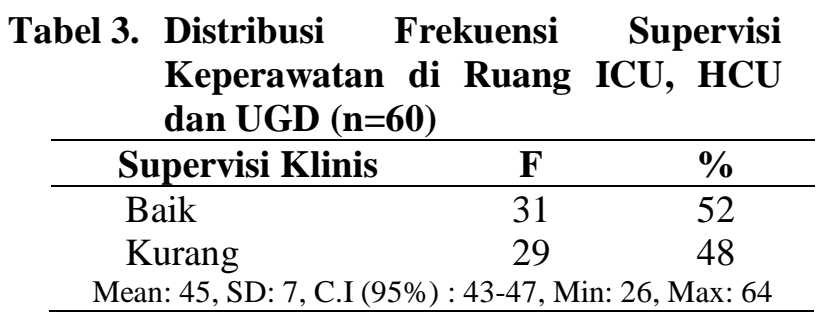

\section{Tabel 4. Analisis Korelasi dan Regresi Supervisi Keperawatan dan Perilaku Caring Perawat Dalam Merawat Pasien Kritis $(\mathbf{n}=60)$}

\begin{tabular}{lcclc}
\hline Variabel & $\mathbf{r}$ & $\mathbf{R}^{2}$ & $\begin{array}{c}\text { Persamaan } \\
\text { Garis }\end{array}$ & $\begin{array}{c}\mathbf{P} \\
\text { value }\end{array}$ \\
\hline Supervisi & 0,502 & 0,252 & Perilaku & 0,000 \\
Klinis & & & Caring $=$ \\
& & \multicolumn{3}{c}{$53,22+$} \\
& & \multicolumn{3}{c}{$0,749 *$ Super } \\
& & & visi Klinis \\
\hline
\end{tabular}


Faletehan Health Journal, 5 (3) (2018) 129-134

www. journal.Ippm-stikesfa.ac.id/ojs/index.php/FHJ

ISSN 2088-673X| 2597-8667

\section{Analisis Bivariat \\ Hubungan Supervisi Keperawatan dengan Perilaku Caring Perawat.}

Hubungan kedua variable dalam penelitian ini yaitu supervise keperawatan dengan perilaku caring perawat dalam merawat pasien kritis dianalisis dengan menggunakan uji korelasi dan regresi linear sederhana yang bertujuan untuk mengetahui kekuatan dan arah hubungan antara variabel supervisi Keperawatan dengan variabel perilaku caring perawat dalam merawat pasien kritis. Hasil Analisis ditunjukkan pada tabel 4.

Hasil analisis pada tabel 4 menunjukan hubungan kedua variable adalah sedang $(r=0,502)$ dan berpola positif yang artinya semakin sering/intens supervisi keperawatan dilakukan maka semakin baik perilaku caring perawat. Nilai koefisien dengan determinasi 0,252 artinya persamaan garis regresi yang diperoleh dapat menerangkan 25,2\% variasi perilaku caring atau persamaan garis yang diperoleh cukup baik untuk menjelaskan variabel perilaku caring.

Perilaku Caring merupakan tindakan nyata perawat dalam melakukan peran dan tugasnya dalam memberikan asuhan keperawatan kepada pasien yang mampu meningkatkan kualitas pelayanan perawatan dalam bentuk perilaku caring yang baik. Hasil analisis menunjukan jika supervisi Keperawatan mempengaruhi perilaku caring perawat, Hal ini sejalan dengan penelitian yang dilakukan oleh Muttaqin (2008)mengatakan jika supervisi memiliki hubungan yang berarti dengan perilaku caring perawat. Penelitian lain telah dilakukan oleh Elzennyet al (2017) tentang pengaruh supervisi klinis dalam meningkatkan kualitas perawatan di intensive care unit dengan hasil terdapat korelasi yang positif antara supervisi klinis terhadap peningkatan kualitas pelayanan perawatan, dimana dalam kualitas perawatan didalamnya termasuk unsur-unsur perilaku caring yang ditunjukan perawat.

Hasil penelitian ini juga sejalan dengan hasil penelitian Harikadua, Warouw, dan Hamel (2011) yang menunjukkan bahwa jika supervisi keperawatan yang baik tentunya akan berdampak pada pelayanan keperawatan yang baik, dan sebaliknya jika supervisi keperawatan masih kurang tentu kualitas perawatan yang diberikan menjadi kurang. Hasil penelitian lain yang dilakukan Mandagi, Umboh, dan Rattu (2015) mengatakan jika ada hubungan antara supervisi yang baik dengan kinerja perawat dalam menerapkan asuhan keperawatan, tentunya dalam asuhan keperawatan didalamnya mengandung unsur dari perilku caring yang ditunjukan oleh seorang perawat.

Pada penelitian ini peneliti melakukan penelaahan terhadap SOP supervisi yang berlaku di RSDP. Pada SOP yang telah ada menunjukkan bahwa aktivitas supervisi lebih banyak didominasi oleh supervisi terhadap tindakan tindakan invasif dan tidak ditemukan aktivitas supervisi terhadap aktivitas komunikasi perawat. Hal ini menyebabkan penilaian responden terhadap kegiatan supervise dalam hal komunikasi menjadi rendah dan tentunya kegiatan supervise belum mampu meniingkatkan kemampuan perawat dalam melakukan komnikasi terhadap pasien, padahal hal ini sangat menentukan kualitas perilaku caring perawat. Terutama dalam merawat pasien kritis, komunikasi dengan pasien maupun keluarga menjadi hal yang sangat dibutuhkan.

Pentingnya supervise dalam kemampuan perawat melakukan komunikasi ssebagai bagian dari perilaku caring tentunya memberikan implikasi pentingnya melakukan revisi terhadap SOP supervise yang ada, sehingga diharapkan dengan semakin intensif nya kegiatan supervise terhadap perilaku komunikasi perawat dapat meningkatkan perilaku caring perawat sehingga semakin meningkatkan kualitas pelayanan keperawatan dalam merawat pasien kritis.

\section{Simpulan}

Hasil penelitian Ini menunjukan jbahwa terdapat hubungan yang signifikan antara supervise keperawatan yang dilakukan oleh kepala ruangan atau pengawas keperawatan terhadap perilaku caring perawat dalamm merawat pasien kritis. Kekuatan hubungan adalah sedang, dengan arah hubungan yang positif. Masih adanya perawat yang mempersepsikan bahwa aktivitas supervisi keperawatan dalam kategori kurang dan perilaku caring perawat yang juga masih kurang menyebabkan RSDP masih perlu untuk melakukan upaya peningkatan melalui pendekatan individu maupun organisasi.

\section{Referensi}

Angelina, R., Kumaat, L., \& Mulyadi. (2015). Hubungan Beban Kerja Perawat dengan Caring Perawat di Instalasi Gawat Darurat Medik prof. Dr. R. D. Kandou Manado. 3(3), $1-8$. 
Desima, R. (2013). Jurnal Keperawatan: Tingkat Stres Kerja Perawat Dengan Perilaku Caring Perawat. Vol 4 (1), 43-55. http://ejournal.Umm.ac.id/index.php/keperaw atan/article/view/2380

Elzenny, S.R., Seada, A.M., \& Etewy, E.A. (2017). Effect Of Clinical Supervision Training Program For Nurse Managers On Quality OfNursing Care In Intensive Care Units. International Journal of Nursng Didactics: Vol 07 (08), 230-240. Dari Link : http://innovativejournal.in

Fazrillah \& Nurfitriani. (2016). Hubungan Stres Kerja dengan Kinerja Perawat Pelaksana dalam Melaksanakan Pelayanan Keperawatan di Instalasi Gawat Darurat Rumah Sakit Umum Anutapura Palu. Jurnal keperawatan Sriwijaya, 3(2). 16-24.

Handayani, A., \& Armina. (2017). Faktor-faktor Yang Berhubungan Dengan Penerapan Komunikasi Terapeutik Oleh Perawat Pada Pasien.Jurnal Akademika Baiturrahim. Vol 06 (02) 1-11.http://stikba.ac.id

Harikadua, A., Warouw, H., \& Hamel, R.S. (2011). Hubungan Supervisi Keperawatan Dengan Kepuasan Kerja Perawat Pelaksana Di Irina C BLU RSUP Prof. Dr. R. D. Kandou Manado.Jurnal Keperawatan: Vol 2, No 2 (2014).https://ejournal.unsrat.ac.id

Indrastuti, Y. (2010). Analisa Hubungan Perilaku Caring Perawat dan Motivasi Perawat dengan Kinerja Perawat Pelaksana Menerapkan Prinsip Etik Keperawatan dalam Asuhan Keperawatan Di RSUD Sragen. Tesis. Diaskes dari : http://lontar.ui.ac.Id

Jakimowich, S., \& Perry, L. (2015). A Concept Analysis of Patient Centered Nursing In The Intensive Care Unit.Journal of Advanced Nursing. $\quad$ Vol 7 (71), 1499-1517. https://www.ncbi.nlm.nih.gov

Kementrian Kesehatan Republik Indonesia. (2012). Perilaku Caring Budaya Perawat Indonesia. Diakses pada tanggal 19 Maret 2018 pada pukul 09.10 WIB dari link http://www.depkes.go.id
Kozier, B., Erb, G., Berman, A., \& Snyder, S.J . (2010). Buku Ajar Fundamental Keperawatan: Konsep, Proses, dan Praktik. Jakarta: EGC.

Lazzerini, M et al. (2017). Improving the Quality of Hospital Care for Children by Supportive Supervision: a Cluster Randomized Trial, Kyrgyzstan.Bulletin of the world Health Organization: Vol 95, 397-407. doi: http://dx.doi.org/10.2471/BLT.16.176982

Mandagi, F.M., Umboh, J.M.L., \& Rattu J.A.M. (2015). Analisis Faktor-Faktor Yang Berhubungan Dengan Kinerja Perawat Dalam Menerapkan Asuhan Keperawatan Di Rumah Sakit Umum BETHESDA GMIM Tomohon.Jurnal e-BiomedikVol 3 (03) 884894.https://ejournal.unsrat.ac.id

Masna., Abdullah, R., \& Hasmin. (2017). Analisis Pengaruh Supervisi Kepala Ruangan, Beban Kerja, dan Motivasi Terhadap Kinerja Perawat. Jurnal Mirai Management. Vol 2 (02), 369-385.http://journal.stieamkop.ac.id

Muttaqin, Z. (2008). Jurnal Keperawatan Indonesia: Pengaruh Pelatihan Supervisi pada kepala Ruangan Terhadap Perilaku Caring Perawat Pelaksana, Tesis, http://www.lib.ui.ac.id

Nurmalasari, A.\& Haryani, A. (2017). Correlation Between emotional Quotient and Caring Behaviorof Nurses in Adult Inpatient Ward. Faletehan Health Journal 4(5) 258-263 2017. http://Journal.lppm-stikesfa.ac.id.

Prayitno, T., Saryono., \& Sarwono. (2011). Hubungan Lama Kerja Perawat Dengan Kepuasan Pasien Paska Bedah di Ruang Perawatan Bedah RS PKU Muhammadiyah Gombong.Jurnal Ilmiah Keperawatan Kesehatan: Vol 7 (02) 110-116. https://ejournal.stikesmuhgombong.ac.id

Tiara., L. A. (2013). Perilaku Caring Perawat Dalam Meningkatkan Kepuasan Pasien Rawat Inap. Jurnal Ilmiah Keperawatan SAI Betik. Vol 09 (02), 115-119. diakses pada tanggal 19/03/2018 pada pukul 11.32 wib dari link: http://ejurnal.Poltekkes-tjk.ac.Id 